\section{Fifty years working to improve food and nutrition in Central America ${ }^{1}$}

1 Based on: Instituto de Nutrición de Centro América y Panamá/ Organización Panamericana de la Salud. INCAP: 50 años de labores en pro del mejoramiento de la alimentación y nutrición en Centroamérica. Guatemala, Guatemala: INCAP/OPS; 1999. Accessed 1 September 1999 at: http://www.incap.org.gt/
A specialized center of the Pan American Health Organization (PAHO) this year is marking a half century working to improve food and nutrition in Central America. Called the Institute of Nutrition of Central America and Panama (INCAP), the center is headquartered in Guatemala City, Guatemala. During its 50 years of existence, the Institute has made major accomplishments in areas that include research, technical cooperation, training, and dissemination of scientific and technical information.

INCAP was officially inaugurated on 16 September 1949 by the Director of the Pan American Health Organization and the Ministers of Health of Costa Rica, El Salvador, Guatemala, Honduras, Nicaragua, and Panama. Since then, Belize and the Dominican Republic have also joined the Institute.

\section{Research on food and nutrition}

Some of INCAP's earliest activities included working with its Member States to conduct clinical and epidemiological trials on the nature, magnitude, distribution, and determinants of the food and nutrition problems of those countries' inhabitants. This research helped identify the most prevalent nutritional deficiencies and guide the countries toward solutions they could apply in line with their own needs and available resources.

In searching for ways to prevent and treat nutritional deficiencies, INCAP was one of the first nutrition centers that contributed to knowledge on the interaction between protein-energy malnutrition, infections, and vitamin A. Studies carried out in Santa María Cauqué, Chimaltenango, Guatemala, showed the synergistic relationship between nutrition and infection. That work also linked low birthweight to such factors as short duration of pregnancy, low maternal size, infection and other illnesses during pregnancy, and short spacing between childbirths. INCAP's efforts to reduce protein-energy malnutrition encouraged the development of approaches that continue to be used in Central America, such as low-cost plant protein mixtures as supplements for infant and preschool feeding, and food and nutrition treatment protocols for malnourished children.

INCAP has been a world leader in developing methodologies to fortify food with vitamin A, iodine, and iron. As part of an effort to prevent en- 
demic goiter, INCAP research helped develop a practical method to fortify salt with iodine, utilizing potassium iodate. Applying that approach, Guatemala was the first developing country to successfully reduce goiter on a nationwide scale. INCAP has also researched the prevention of severe vitamin A deficiency through sugar fortification with retinol, as well as simple and practical methods for surveillance and quality control of iodine fortification of salt and vitamin A fortification of sugar.

In operation since 1969, the INCAP Longitudinal Study of Growth and Development has helped build recognition of the usefulness of anthropometric indicators as practical tools to evaluate the nutritional status of populations and to determine the effectiveness of nutrition interventions. That work has also been key to a better understanding of fetal growth patterns, causes of intrauterine growth retardation among malnourished populations, and patterns and causes of postnatal growth retardation. This research has clarified the role that maternal size and diet have on intrauterine growth and has shown that infectious diseases, especially diarrheal ones, and deficient dietary intakes are the principal determinants of inadequate growth during infancy. The INCAP studies have also demonstrated that most growth deficiencies are related to poverty rather than genetics; that nutritional interventions are highly effective in preventing inadequate growth, especially when they are targeted toward mothers and children; and that nutritional interventions early in life, during the intrauterine period and in a child's first two to three years of life, are fundamental for the optimal growth and development of adolescents and young adults.

In the field of the food technology, INCAP research has led to genetically and nutritionally improved varieties of corn; to supplements to enrich tortillas; and to a better understanding of nixtamalización, or the process of adding lime to corn and other grains, and the effect that it has on nutritional value. Given the importance that legumes have as complementary protein in Central America, INCAP has carried out numerous research projects on common beans, in terms of production, processing, storage, availability, and consumer acceptance. In the field of the animal nutrition, INCAP researchers have investigated areas that include calf production with minimum milk consumption, utilizing coffee pulp in animal feeding, and potential nontraditional foods for animals.

Among many researchers during the 1950s and 1960s, problems of food and nutrition were viewed primarily from a medical and biological perspective. However, through its anthropological and economic studies, INCAP moved beyond that more limited point of view, to a much broader so- ciocultural and economic understanding of nutritional issues. The Institute was a pioneer in developing models that could identify groups at risk, help set priorities, and identify appropriate roles for various sectors in solving food and nutrition problem. This socioeconomic research has looked at a wide range of issues. For example, with support from the French Institute of Research for Development in Cooperation, INCAP studied trends in wages in relation to the prices of the main foods and household fuels in Central America. Other research investigated the effects that chronic energy deficiency had on farmers' productivity and income.

\section{Building people's skills in all the countries}

Since its establishment, the Institute has played a key role in education and training on food and nutrition. Thousands of professionals who received INCAP training now occupy leadership positions in the public, private, and academic sectors. INCAP training methods have included seminars, short courses, creation of a regional and then national schools of nutrition, and even a master's degree program. In the short courses given in the various countries, some 40000 staff members have received training on food and nutrition. Since being started in 1989, distance learning programs have reached approximately 10000 physicians, nurses, and nutritionists, in Central America, elsewhere in Latin America, and in other regions of the world.

\section{Technical cooperation}

From its founding, INCAP's scientific and technical cooperation has been central to helping the Member States solve their nutrition problems. In recent years, that technical cooperation has focused on food systems, food fortification, food and nutrition planning, education and food and nutrition, and health and nutrition. In the area of food systems, for example, INCAP has provided technical cooperation on experiences at the local level in producing basic grains, postharvest management, and preparation of compound flours; organization and implementation of rural food agroindustries; and technology transfer for the preparation of nutritionally improved foods. INCAP work on food fortification has included promoting model legislation on food fortification and enrichment, technical and economic feasibility studies of the market for fortifying sugar with vitamin A in Nicaragua and the Dominican Republic, and training courses for the Central American food industry in good manufacturing practices and on specific technological processes. In 
the area of food and nutrition planning, INCAP has investigated the relationship between minimum wages and food costs in Central America, as well as formulated plans, policies, and projects on food safety and nutrition. Efforts on education, food, and nutrition have included reviewing and adding food and nutrition materials to training school curricula, supporting school feeding programs, conducting height surveys of children in the first grade, and preparing and disseminating nutritional guidelines. In the area of health and nutrition, INCAP's technical cooperation activities have supported micronutrient deficiency prevention and control efforts, national surveys on micronutrients in Central America, risk factor assessments, and actions to prevent chronic noncommunicable feeding-related illnesses.

\section{Disseminating scientific and technical information}

INCAP has widely disseminated scientific and technical information, through materials that include approximately 3000 scientific articles, some 80 monographs, and 350 collaborative works with academic centers. Findings from INCAP's work have appeared in undergraduate and graduate theses, and have been further disseminated at scientific fora and other professional events. INCAP has also increased the availability of scientific information and strengthened the capacity of country-level documentation centers by providing packages of Spanishlanguage documents and distributing bulletins and technical sheets on various topics related to food and nutrition.

Some of INCAP's publications have been notable for their ongoing usefulness. Of particular significance have been documents on the composition of traditional and nontraditional foods of Latin America, the composition of grasses and forage crops of Central America and Panama, daily nutritional recommendations for Central America and Panama, and reports on nutrition surveys in Central America.
INCAP's work has also gone to other regions of the world, providing valuable information on such topics as standard methodologies for fortifying salt with potassium iodate and on measurement and anthropometric standardization.

\section{Looking to the future}

During the 1990s, INCAP has added to its ongoing activities by supporting the Central American Nutrition and Food Security Initiative. Put forward by the ministers of health of the Member States, that measure was endorsed by the Central American presidents during a summit held in Guatemala in October 1993.

As INCAP continues working in the coming decades to improve food and nutrition in Central America, the Institute will face special challenges in many areas. These will include changes in the socioeconomic and political situation in Central America and elsewhere in the world, population growth, migration to the cities, effects from globalization, the process of Central American integration, free trade agreements, climatic changes, environmental issues, and new technological developments.

\section{SINOPSIS}

\section{Cincuenta años de trabajo para mejorar la alimentación y nutrición en Centroamérica}

El Instituto de Nutrición de Centroamérica y Panamá (INCAP), un centro especializado de la Organización Panamericana de la Salud con sede en la ciudad de Guatemala (Guatemala), cumple este año medio siglo de trabajo dedicado a mejorar la alimentación y nutrición en Centroamérica. El Instituto ha conseguido importantes logros en diferentes áreas, que incluyen la investigación, la cooperación técnica, la formación y la diseminación de información científica y técnica. 